Predrag Ž. Živković

University of Kragujevac

Faculty of Education in Jagodina

Department of Humanities and

Social Sciences
УДК: $371.279 .1-057.8$

$159.923 .2-057.8$

https://doi.org/10.18485/uzdanica.2020.17.2.17

Оригинални научни рад

Примљен: 30. септембар 2020.

Прихваћен: 23. новембар 2020.

\title{
DEFERMENT OF ACADEMIC OBLIGATIONS AND UNIVERSITY STUDENTS SELF-HANDICAPPING: PROCRASTINATION IN AN ACADEMIC CONTEXT
}

\begin{abstract}
Although there is no uniquely accepted definition, procrastination is usually defined as willing, irrational delay of planned activities, despite the knowledge that it will have negative consequences for an individual. Self-handicapping, as a strategy for coping with potential failure, occurs when there is a threat of self-esteem, that is, when a failure in an activity most commonly associated with ability is expected. The individual then actively seeks or creates factors that impede the performance of that activity, which can serve as justification for a potential failure. The aim of the research was to determine the connection between academic procrastination and student self-handicapping. In addition, a sample of one hundred ninety-eight students of the Faculty of Education $(\mathrm{N}=158)$ was used to examine the factor structure of the instruments used (Procrastination Scale (Tuckman 1991), Self-handicapping Scale (Jones, Rhodewalt 1982), concurrent and discriminative validity of the scales, as well as predictive and classification values of the model in standard and hierarhical regression analysis (gender, study level, procrastination, self-handicapping, self-esteem, resilience, imposterism, burnout, self-directed learning). The results show that $54 \%$ of students procrastinate; that procrastination is explained by one dimension and self-handicapping by two (behavioral and proclaimed self-handicap); that the correlation of procrastination with behavioral self-handicapping is statistically significant $(\mathrm{r}=0.64)$, and that the association of procrastination with claiming self-handicapping is not statistically significant $(r=0.10)$; that female respondents procrastinate more than male subjects; that weaker procrastinators self-handicap themselves differently (behavioral-claimed) while stronger procrastinators self-handicap themselves similarly; that based on standardized $(\beta)$ beta coefficients in the regression analysis, it can be concluded that the strongest predictors of procrastination are gender and claimed self-handicapping. These data point to a relatively large number of those who are delaying their academic responsibilities, hence academic procrastination is a problem of epidemiological proportions among college students.
\end{abstract}

Keywords: procrastination, self-handicapping, academic context, correlation analysis. 


\section{THEORETICAL BACKGROUND}

Procrastination can be defined as a needless delay of a relevant and timely task. Chronic procrastination is related to a host of traits, including low self-confidence and self-esteem and high depression, neurosis, self-awareness, social anxiety, forgetfulness, disorganization, non-competitiveness, dysfunctional impulsivity, behavioral rigidity, and lack of energy (Beswick, Rothblum, Mann 1988; Ferrari 2004; Ferrari, Johnson, McCown 1995; Lay 1986; Senecal, Koestner, Vallerand 1995). Review of the literature also suggests that procrastination is related to low conscientiousness, low self-esteem, and low self-efficacy (Van Eerde 2003, 2004).

Procrastination is a commonly observed self-handicapping behaviour (Steel 2007). Observed or reported procrastination has often been used as a proxy for self-handicapping (Ferrari, Tice 2000). However, procrastination alone does not necessarily indicate the presence of a self-handicapping motive. Procrastination that has no implication for failure on an evaluative task might be a product of laziness or disengagement. However, when procrastination does have an implication for failure it may indicate self-handicapping. Given this, measures of self-handicapping should positively correlate with measures of procrastination, but not to a degree that would suggest that they are the same construct.

The term self-handicapping was created and first presented to the scientific community in 1978 by the American researchers Berglas and Jones. According to the authors, self-handicapping strategies are strategies (excuses and behaviors) created by a person while performing a task that is important for them while not feeling capable of performing it (Berglas, Jones 1978; Harris et al. 1986; Kolditz, Arkin 1982). Self-handicapping strategies can be used in many contexts, such as management, sports and education. The frequent use of these strategies jeopardizes performance and interferes with success (Finez, Sherman 2012; McCrea et al. 2008; Smith, Hardy, Arkin 2009).

\section{METHOD}

\section{AIM AND HYPOTHESES}

The aim of the research was to determine the connection between academic procrastination and university students self-handicapping. There are four hypotheses in this study. First, the procrastination and self-handicapping will reflect multiple factors (H1). Such an interpretation is supported by previous multifactorial solutions (McCrea et al. 2008; Rhodewalt 1990; Zuckerman et al. 1998). Second, it is possible to establish a model with good fit-indices with the obtained component structure, which can confirm the connection between procrastination and selfhandicapping dimensions (H2). Third, we assume that the chosen set of correlates 
contributes to the discriminant validity of procrastination and self-handicapping (H3) measurements. Four, the different self-handicapping components will incrementally predict university students procrastination (H4). This will provide further evidence for the distinctiveness between self-handicapping factors and the importance of considering self-handicapping as a predictor of academic procrastination.

\section{PARTICIPANTS}

The initial sample of respondents consisted of 158 students from University of Kragujevac, Faculty of Education in Jagodina - 54.1\% of students of the 2nd year undergraduate Class teacher education study program and $45.9 \%$ of students of the 3rd year undergraduate and master postgraduate Class teacher education study program. Among 158 participants, there were 131 (83\%) women and 27 $(17 \%)$ men $(\mathrm{M}=1.83, \mathrm{SD}=.375), 50(32 \%)$ postgraduate and $108(68 \%)$ undergraduate students $(\mathrm{M}=1.06, \mathrm{SD}=.206)$. Test distribution for academic achievements is normal (Kolmogorov-Smirnov $\mathrm{Z}=1.999, \mathrm{p}=0.001, \mathrm{M}=2.46, \mathrm{SD}=.706$ ).

\section{MEASURES}

Procrastination Scale (Tuckman 1991) - 16-item procrastination measure. In Tuckman's validation study, the measures showed adequate validity and reliability (Cronbach's alpha $\alpha=0.88$ ). In the present study, calculated Cronbach's alpha was $\alpha=0.87$ (for 15 -item after conducting an inter-item and factor analysis). It is used for self-report measure of procrastination tendencies and to investigate its relationship to a behavioral measure of procrastination and to a self-report measure of correlated variables. In a subsequent study on 183 college students, a factor analysis of scores on the 35-item scale yielded a single-factor structure and a condensed scale of 16 items with a reliability of $\alpha=0.86$. In our verification, by eliminating items with deficit communalities and low factor scores and loadings, a five-item version was obtained that gives good fit-indices in the CFA model presented in this study. This shortened version of the procrastination scale was recommended for use as a means of detecting students who may tend to procrastinate in the completion of college requirements.

Self-handicapping Scale (Rhodewalt, Jones 1982). SHS is a 25 -item selfreport invetory answered on six-point Likert scale. This 25 -item questionnaire has a six-point Likert response scale ranging from (1) 'strongly disagree' to (6) 'strongly agree'. The 25-item SHS is the most widely used self-report measure of selfhandicapping in psychological research studies. It was constructed to identify selfhandicapping tendencies as a general trait (Rhodewalt 1990). Although research studies to date suggest that the SHS may be factorially complex, there has been a 
lack of agreement about which factor structure best represents self-handicapping (as measured by the SHS). Both unidimensional and multifactorial structures have been found. McCrea, Hirt, Hendrix, Milner and Steele (2008) suggested a twofactor structure of the SHS. They labelled their factors 'claimed' and 'behavioural', differentiating between self-handicapping behaviours that actually took place (behavioral), and those that were only said to have taken place (claimed). In our sample, the result obtained for Crombach's alpha reliability coefficient is $\alpha=0.78$ (behavioral self-handicapping) and $\alpha=0.83$ (claimed self-handicapping).

Clance Imposter Phenomenon Scale (Clance 1985). There are two versions, the original scale with 20 items and the short version with 16 items. Both versions of the instrument have been tested, the 20 -item version and the 16 -item version. SPSS 17.0 was used for statistical processing and a defined version of rawpar. spss syntax was used for parallel analysis (O'Connor 2000). The Cronbach's alpha reliability coefficient for 20-item scale (CIPS-20) was $\alpha=0.81$. The results of the parallel analysis, for the first version of the scale CIPS-20, indicate the justification of accepting two factors. The characteristic values of the two components exceed the corresponding threshold values obtained using an equally large matrix of random numbers. The obtained correlation between these two factors is $r=0.38$. Two factors are interpreted as true imposters (1) and strategic imposters (2) (Leonhardt, Bechtoldt, Rohrmann 2017).

Rosenberg Self-Esteem Scale (RSES) (Rosenberg 1965; Todorović 2005). The RSES assesses the overall sense of being capable, feeling worthwhile, and competent. Internal consistency and factor validity of the Serbian version of the RSES were shown to be high (Todorovic 2005). The scale consists of 10 items, and the degree of self-esteem for each item is rated on a 7-point Likert scale (range 10-77). In the present study the internal reliability by Cronbach's alpha coefficient is $\alpha=0.78$.

Maslach Teachers Burnout Inventory -Educators Survey (MBI -ES) (Maslach 1986). This scale consists of 22 items. Generally speaking, on our sample of teachers the instrument shows satisfactory metric characteristics (Živković, Grozdanović 2015). The reliability was determined with Crombach's alpha coefficient. The internal reliability of the questionnaire is over 0.60 (Crombach's alpha coefficient $\alpha=.604$, with standardization value of $\alpha=.633$ ).

Resilience Scale - RS14 (Wagnild, Young 1993). In order to provide clinicians and researchers with a shorter instrument for reducing the burden on participants, a short version of RS (RS-14) (Vagnild 2009) was developed. Cronbach's alpha of the RS-14 has been reported to be excellent $(\alpha=.93)$ and it correlates strongly $(r=.97)$ with the original RS (Wagnild 2009a). In the present study, the calculated Cronbach's alpha was $\alpha=.84$.

Self-directed Learning Assessment Scale (Williamson 2007). The author defined a preliminary sample of items $(\mathrm{N}=75)$. After the interstate reliability analy- 
sis, a final version of the test consisting of 58 items was obtained. Factor analysis identifies five dimensions (subscales): awareness, learning strategies, learning activities, evaluation, and interpersonal skills. The scale is of the Likert type, with rating alternatives from 1 (never) to 5 (always).

\section{PROCEDURE}

The survey was conducted anonymously and voluntarily at the Faculty of Education in Jagodina. The translation of the scales from English into Serbian was accomplished by a professional translator. The aim of the translation was not to achieve literal or syntactic equivalence, but to maintain the original denotation and connotation of items.

Cronbach's alpha coefficient, the test-retest correlation coefficient, and the correlations between the STPIS and other measures were established by calculating Pearson's correlation coefficients. Exploratory factor analysis (EFA), parallel analysis (PA) and confirmatory factor analysis (CFA) were conducted by using data at initial assessment. For all statistical analyses two-tailed tests were used. For all statistical evaluations, $\mathrm{p}$-values less than 0.05 were considered indicative of significant differences. The statistical analyses were conducted using the Statistical Package for the Social Sciences (SPSS) for Windows, version 17.0. For statistical analysis, p-values lower than 0.05 were considered statistically significant. The normality of the total scores of PS and SHS was evaluated by using the Kolmogorov-Smirnov test of normality. Reliability and internal consistency (inter-item correlation) for PS and SHS were assessed using Cronbach's alpha coefficient. The correlations between both scale scores and self-reported self-esteem, resilience, imposterism, burnout stress, and self-directed learning were calculated by using Pearson's correlation coefficient (one-tailed significance). To evaluate and confirm the factor structures in components analysis, a confirmatory factor analysis was done with LISREL 9.30.

\section{RESULTS}

Exploratory factor analysis and parallel analysis. In dimension reduction analysis, we used three procedures to determine the number of instrument components we used to measure procrastination and self-handicap: exploratory factor analysis (from PCA), parallel analysis (PA), and confirmatory factor analysis (standard solution in CFA).

The factor analysis, from a principal component extraction with Varimax rotation of the procrastination scale offered an initial four-component solution, which we checked in the second step with a parallel analysis. The parallel analysis 
confirmed the acceptance of only one component whose characteristic value exceeds the corresponding threshold values. This component, after eliminating others with a negligibly small percentage of explanation of variance, consists of five items (items 5, 6, 8, 14, and 15 from the basic set of scale items; Tuckman 1991). The obtained Cronbach's alpha reliability coefficient is $\alpha=0.79$.

In the assessment of the self-handicapping scale dimensions, the factor analysis singled out a seven-component solution. The parallel analysis confirmed the existence of only two components, namely those with significantly higher eigenvalues from factor analysis and factor loads (total cumulative percentage of $45.43 \%$ of the explained variance). Items from both factor solutions coincide with a set of factor items from the author's basic check (validation and internal consistency check; Jones, Rhodewalt 1982). Therefore, we interpreted them identically, as behavioral self-handicapping $(\alpha=0.83)$ and claimed self-handicapping $(\alpha=0.87)$. After this, in the confirmatory factor analysis, we evaluated the model obtained in this way.

Confirmatory factor analysis. To evaluate and confirm the factor structures of both scales, confirmatory factor analysis was done with LISREL 9.30. The Goodness-of-Fit Index (GFI), the Adjusted Goodness-of-Fit Index (AGFI), the Comparative Fit Index (CFI), and the Root Mean Square Error of Approximation (RMSEA) were used to evaluate the fit of the models using the following criteria: GFI > .90, AGFI > .90, CFI > 95 and RMSEA <.06 (Barret 2007; Kline 2005; McCallum1996; Miles, Shevlin 1998; Hu, Bentler 1999; Hu, Bentler 1999; Bentler, Bonnet 1980; Mulaik et al. 1989; all normes according to: Azman, 2017).

Table 1. Summary of fit-indices for the present model (one procrastination (five items) two self-handicapping factors)

\begin{tabular}{llll}
\hline & Goodnes-of-fit indices & Results & Norm \\
\hline 1. & $\chi^{2}$ p-value & 0.212 & $\geq .05$ (Barret 2007) \\
2. & RMSEA & 0.077 & $\leq 05$ (McCallum 1996) \\
3. & GFI & 0.915 & $\geq .90$ (Miles, Shevlin 1998) \\
4. & AGFI & 0.817 & $\geq .80$ (Hu, Bentler 1999) \\
5. & SRMR & 0.057 & $\leq 05$ (Byrne 1998) \\
6. & NFI & 0.836 & $\geq .90$ (Bentler, Bonnet 1980) \\
7. & NNFI & 0.926 & $\geq .80$ (Bentler, Bonnet 1980) \\
8. & CFI & 0.915 & $\geq .90$ (Bentler 1990) \\
9. & PGFI & 0.925 & $\geq .90$ (Mulaik et al. 1989) \\
\hline
\end{tabular}

The path diagram shows satisfactory values of uniqueness for all selected variables. It is possible to predict both latent variables based on the set variables in the model, except for self-handicapping based on behavioral selh-handicapping. 
Figure 1. Path diagram for confirmatory factor analysis (standard solution).

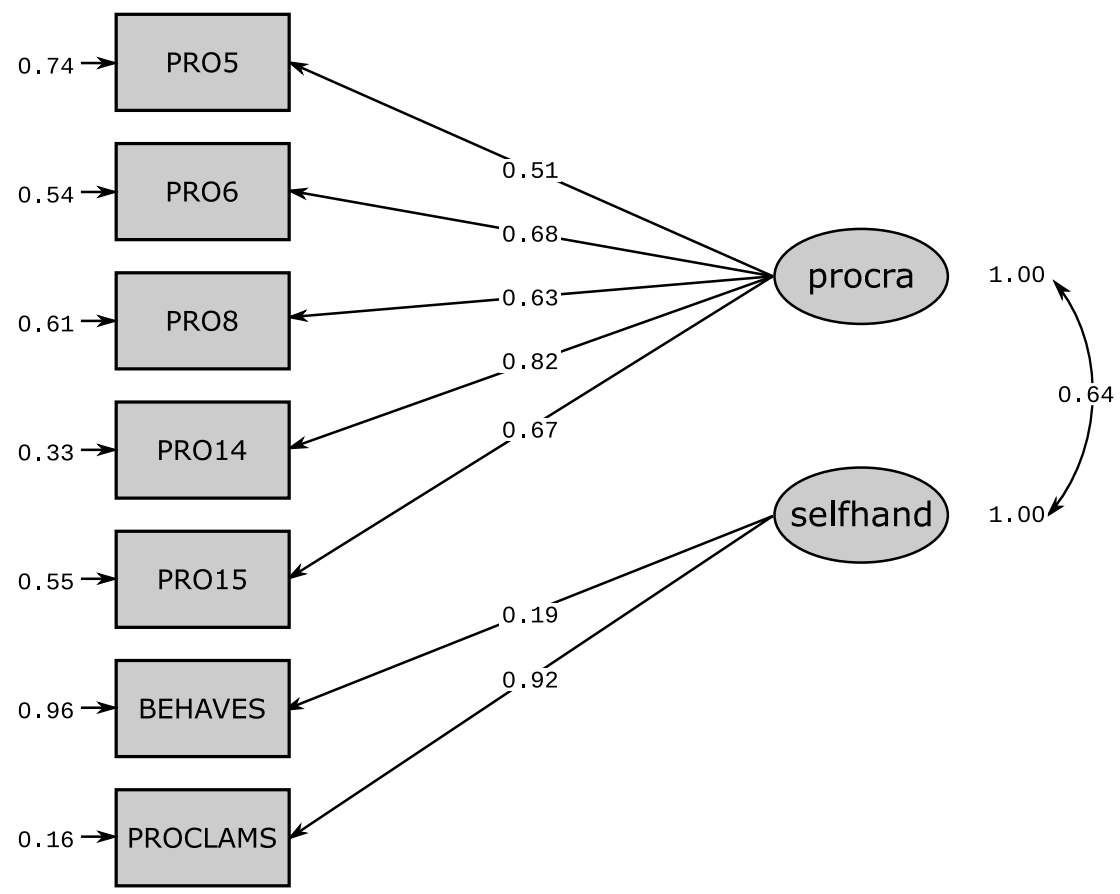

Chi-Square $=16.73, \mathrm{df}=13, \mathrm{P}$-value $=0.21196, \mathrm{RMSEA}=0.077$

The obtained indicators of descriptive statistics and reliability coefficient are shown in the Table 2.

Table 2. Scales descriptive statistics and reliability coefficients

\begin{tabular}{lrrrrc}
\hline & Minimum & Maximum & Mean & Std. Deviation & $\alpha$ \\
\hline Procrastination & 5,00 & 25,00 & 16,4694 & 4,65968 & 0,79 \\
Behavioral self-handicapping & 4,00 & 20,00 & 15,0204 & 3,69397 & 0,78 \\
Claimed self-handicapping & 1,00 & 17,00 & 7,5714 & 4,46748 & 0,83 \\
Resilience & 57,00 & 125,00 & 97,5060 & 12,80851 & 0,84 \\
True imposter & 19,00 & 47,00 & 29,0000 & 8,28344 & 0,64 \\
Strategic imposter & 15,00 & 27,00 & 23,2143 & 3,51215 & 0,76 \\
Self-esteem & 19,00 & 50,00 & 33,3486 & 6,49449 & 0,78 \\
Burnout & 8,00 & 92,00 & 57,6593 & 11,37074 & 0,63 \\
Awereness SDL & 26,00 & 56,00 & 48,3902 & 5,25775 & 0,79 \\
Learning strategy SDL & 28,00 & 54,00 & 44,0000 & 5,80086 & 0,73 \\
Learning activity SDL & 27,00 & 58,00 & 45,3659 & 6,20385 & 0,71 \\
Evaluation SDL & 27,00 & 54,00 & 44,2195 & 5,40607 & 0,69 \\
Inter-relationship skills SDL & 29,00 & 52,00 & 45,0488 & 4,98473 & 0,80 \\
\hline
\end{tabular}


Independent t-test results of group comparisons show that there are statistically significant differences with respect to gender only regarding procrastination (male $\mathrm{M}=11.285, \mathrm{SD}=4.71$; female $\mathrm{M}=17.333, \mathrm{SD}=4.10 ; \mathrm{t}=3.541$, $\mathrm{p}=0.014$ ) and behavioral self-handicapping (male $\mathrm{M}=17,571, \mathrm{SD}=1,133$; female $\mathrm{M}=14,595, \mathrm{SD}=3,806 ; \mathrm{t}=2,037, \mathrm{p}=0,000)$.

Correlation. For the purpose of determining the discriminant and concurrent validity of selected instruments, correlations with scores on scales for measuring the following psychological variables of interest were calculated: resilience, selfesteem, imposterism, burnout, and self-directed learning. The obtained results are shown in the Table 3.

Table 3. Correlation matrix for variables of interest

\begin{tabular}{lccc}
\hline & Procrastination & Behavioral SH & Claimed SH \\
\hline Resilience &,- 090 &, 030 &, 053 \\
True imposter &, $383^{*}$ &, $281^{*}$ &, $590^{* *}$ \\
Strategic imposter &, $507^{* *}$ &, 040 &, $536^{* *}$ \\
Self-esteem &, $261^{*}$ &,$- 335^{*}$ &, $254^{*}$ \\
Burnout &, 054 &, 130 &, 088 \\
Awereness SDL &, 121 &,- 122 &, 126 \\
Learning strategy SDL &, 079 &,$- 371^{*}$ &, 055 \\
Learning activity SDL &, 197 &,$- 296^{*}$ &, 048 \\
Evaluation SDL &, 162 &,$- 251^{*}$ &,- 089 \\
Inter-relationship skills SDL &, 102 &,$- 340^{*}$ &, 116 \\
\hline
\end{tabular}

\footnotetext{
Note: $\mathrm{SH}$ - Self-Handicapping; SDL - Self-Directed Learning

** Correlation is significant at the 0.01 level (2-tailed)

* Correlation is significant at the 0.05 level (2-tailed)
}

The correlation between procrastination and claimed self-handicapping is $\mathrm{r}=.538$, and between procrastination and behavioral self-handicapping $\mathrm{r}=.108$. The correlation between two self-handicapping factors is $r=.179$. The correlation between procrastination and self-handicapping (from standard solution fit indices) is $r=.64$.

Standard regression analysis. How well do two self-handicapping measures predict procrastination? How much of the variance in the procrastination measurement results can be explained by the values of the results from the self-handicap scale? Which trait predicts procrastination better: behavioral or claimed self-handicapping? The answers to these questions will be given by regression analysis.

Table 4. Model summary for standard regression

\begin{tabular}{|c|c|c|c|c|c|c|c|c|c|}
\hline \multirow[t]{2}{*}{ Model } & \multirow[t]{2}{*}{$R$} & \multirow[t]{2}{*}{ R Square } & \multirow{2}{*}{$\begin{array}{l}\text { Adjusted } \\
\text { R Square }\end{array}$} & \multirow{2}{*}{$\begin{array}{l}\text { Std. Error } \\
\text { of the } \\
\text { Estimate }\end{array}$} & \multicolumn{5}{|c|}{ Change Statistics } \\
\hline & & & & & $\begin{array}{l}\text { R Square } \\
\text { Change }\end{array}$ & F Change & $\mathrm{df1}$ & $\mathrm{df} 2$ & $\begin{array}{c}\text { Sig. F } \\
\text { Change }\end{array}$ \\
\hline 1 & ,538 & ,290 & ,259 & 4,01104 & 290 & 9,390 & 2 & 46 & ,000 \\
\hline
\end{tabular}


The coefficient of determination $\mathrm{R}^{2}=0.290$ was obtained; the model (behavioral and proclaimed self-handicapping) explains $29 \%$ of the procrastination variance. Obtained Adjusted $\mathrm{R}^{2}=0.259$ (recommended for small samples). From the ANOVA table we can determine the statistical significance of this indicator (test results of the null hypothesis that $\mathrm{R}^{2}=0$ ). The model in our case reaches statistical significance (Sig. $=0.000 ; \mathrm{p} \leq 0.05$ ).

The standardized Beta coefficient, which we used here to compare the contribution of both independent variables, shows that claimed self-handicapping ( $\beta=0.536)$ contributes significantly more to the explanation of procrastination than behavioral self-handicapping $(\beta=0.013)$. This variable makes a significant unique contribution to the prediction of procrastination $(\mathrm{Sig} .=0.000)$. Semipartial correlation coefficient $(\mathrm{Part}=0.527)$ indicates a $27 \%$ variance in procrastination that can be uniquely explained by proclaimed self-handicap.

Hierarchical multiple (sequential) regression analysis. We performed a hierarchical multiple regression analysis in four blocks. In the first block, we included gender of the respondents and the study program into the analysis of the variable. This changed the statistical influence of these variables.

Table 5. Model summary for hierarhical regression

\begin{tabular}{|c|c|c|c|c|c|c|c|c|c|}
\hline \multirow[t]{2}{*}{ Model } & \multirow[t]{2}{*}{$\mathrm{R}$} & \multirow[t]{2}{*}{ R Square } & \multirow{2}{*}{$\begin{array}{l}\text { Adjusted R } \\
\text { Square }\end{array}$} & \multirow{2}{*}{$\begin{array}{l}\text { Std. Error } \\
\text { of the } \\
\text { Estimate }\end{array}$} & \multicolumn{5}{|c|}{ Change Statistics } \\
\hline & & & & & $\begin{array}{l}\text { R Square } \\
\text { Change }\end{array}$ & F Change & df1 & df2 & $\begin{array}{c}\text { Sig. F } \\
\text { Change }\end{array}$ \\
\hline 1 & ,545 & ,297 & ,239 & 3,48807 & 297 & 5,072 & 1 & 12 & ,044 \\
\hline 2 & 812 & ,659 & ,557 & 2,65978 & ,362 & 5,319 & 2 & 10 & 027 \\
\hline 3 & ,851 & 724 & ,488 & 2,86113 & ,065 & ,547 & 3 & 7 & ,666 \\
\hline 4 & ,886 & 785 & ,303 & 3,33793 & ,061 & 381 & 3 & 4 & ,773 \\
\hline
\end{tabular}

In the second step, we inserted a block of variables of interest (behavioral and proclaimed self-handicapping), and in the next two correlates. After entering the variables in Block 1 (gender, study program), the whole model explains 29.7 percent variance $($ Sig. F change $=0.044$ ), variables in Block 2 (behavioral and proclaimed self-handicapping), the model as a whole explains 65.9 percent of the variance. In this block, 36.2 percent of the variance was explained that explains the variables behavioral and proclaimed self-handicapping (Sig. F change $=0.027$ ). $\mathrm{F}=6.454, \mathrm{p}=0.010$ ) The variables included in Block 3 and Block 4 add a negligibly small percentage of explanation of variance that is not statistically significant.

To determine how much each variable contributes to the final equation, we use coefficient indicators: two variables make a statistically significant contribution, namely gender $(\beta=.569)$ which explains 32.4 percent of the procrastination variance $(\mathrm{SCC}=0.563)$, and claimed self-handicapping $(\beta=.615)$ which explains 36.12 percent of the procrastination variance $(\mathrm{SCC}=0.601)$. 


\section{DISCUSSION}

This study aimed to analyze the procrastination and self-handicapping strategies of college students and examine the relationship between the reported use of these strategies and the variables 'gender' and 'study program', as well as psychological correlates: self-esteem, imposterism, resilience, burnout, and self-directed learning. Generally, most participants reported the use of self-handicapping behaviors in the academic context, such as procrastination (54\%). According to the literature, this result was expected and has important educational implications because these behaviors can affect learning and jeopardize student performance (Gadbois, Sturgeon 2011; Leary, Shepperd 1986; Leondari, Gonida 2007; Schwinger, Stiensmeier-Pelster 2011).

In the present study, factor analysis shows that procrastination can be interpreted as a one-dimensional trait, and self-handicapping as a two-dimensional construct (CFA indices good-fit; RMSEA =0.077, GFI=0.915, AGFI =0.817). Although similar, these two types of strategy differ in terms of harm to academic performance and are related to external judgment (Gadbois, Sturgeon 2011; Hirt et al. 1991; Leary, Shepperd 1986). In our study, we obtained confirmation for differentiation; the correlation between these two types of self-handicapping is not statistically significant $(\mathrm{r}=0.17)$. Correlation between procrastination and claimed self-handicapping is $\mathrm{r}=0.53$, and procrastination and behavioral self-handicapping $\mathrm{r}=0.10$.

The obtained correlation between two self-handicapping factors is $r=0.17$. The correlation between procrastination and self-handicapping (from standard solution fit indices) is $r=0.64$. Ferrari (1990) obtained a slightly lower correlation between procrastination and self-handicapping $(r=0.29)$ in his seminal paper. The obtained correlations between self-esteem and procrastination and behavioral and claimed self-handicapping are in line with the results of previous research (Rhodewalt 1990; Strube 1986; Zuckerman et al. 1998; Urdan, Midgley 2000; Van Eerde 2003, 2004).

It may be interesting that statistically significant correlations of procrastination and self-handicapping with both types of imposterism (true and strategic imposter) were obtained. Although we have not found in the available research studies that links between these two variables have been established and given the nature of the imposter phenomenon, such results are not surprising - although it can be assumed that this could be a spillover of similar entities.

Claimed self-handicapping ( $\beta=0.536)$ contributes significantly more to the explanation of procrastination than behavioral self-handicapping $(\beta=0.013)$. This variable makes a significant unique contribution to the prediction of procrastination (Sig. $=0.000)$. Likewise, two variables make a statistically significant contribution to explaining procrastination variance, namely gender $(\beta=0.569)$, which explains $32.4 \%$ of procrastination variance $(\mathrm{SpC}($ semi-partial correlation $)=0.563)$, and 
claimed self-handicapping $(\beta=0.615)$, which explains $36.12 \%$ of the procrastination variance $(\mathrm{SpC}=0.601)$. Therefore, it could be stated that our procrastinators are not self-handicappers in the true sense of the word. They are self reported self-handicappers, or claimed self-handicappers.

\section{CONCLUSION}

It would be interesting to notice that the participants of the study, despite reporting the use of self-handicapping strategies, seemed aware of the impact of their actions on academic performance and are concerned about their professional training. These same students also reported that reflecting on actions that are detrimental to learning is a crucial step toward changing their behavior, enhancing their learning and academic performance and becoming good professionals. It is clear that these data are highly promising, particularly because they were collected from individuals who aspire to be teachers.

Given these results and the paucity of Serbian publications on the use of selfhandicapping strategies, it is evident that further research on this topic is needed. In addition to identifying these behaviors, it could be interesting to propose ways to reduce the frequency of their occurrence in the academic setting. It can be expected that once students become informed regarding what these strategies are and how to minimize their use, they will be more able to modify their behavior.

As the sample consisted of students from Class teacher education study program, it is essential to consider that these students are preparing to become teachers of children and teenagers who, in turn, could be using the same self-handicapping strategies and procrastination reported in this study. In addition to benefiting students, it is expected that if students have a better understanding of these behaviors, they will be able to identify self-handicapping attitudes, guide their students by providing better methods to deal with these attitudes and help them develop more favorable behaviors toward learning.

\section{REFERENCES}

Azman (2017): A. H. N. Azman, SEM: Confirmatory factor analysis (CFA), Inspiora Resources.

Berglas, Jones (1978): S. Berglas, E. E. Jones, Drug choice as a self-handicapping strategy in response to noncontingent success, Journal of Personality and Social Psychology, 36(4), 405-417.

Burka, Yuen (1983): J. B. Burka, L. M. Yuen, Procrastination: Why you do it, what to do about it, Reading, MA: Addison-Wesley.

Clance (1985): P. R. Clance, The Impostor Phenomenon, Atlanta: Peachtree. 
Ferrari (1991a): J. R. Ferrari, A preference for a favorable public impression by procrastination: Selecting among cognitive and social tasks, Personality and Individual Differences, 12, 1233-1237.

Ferrari (1991b): J. R. Ferrari, Self-handicapping by procrastinators: Protecting social-esteem, self-esteem, or both?, Journal of Research in Personality, 25, 245-261.

Ferrari (1993): J. R. Ferrari, Christmas and procrastination: Explaining lack of diligence at a "real-world" task deadline, Personality and Individual Differences, 14, 25-33.

Ferrari (1994): J. R. Ferrari, Dysfunctional procrastination and its relationship with self-esteem, interpersonal dependency, and self-defeating behaviors, Personality and Individual Differences, 15, 673-679.

Ferrari (2001): J. R. Ferrari, Procrastination as self-regulation failure of performance: Effects of cognitive load, self-awareness, and time limits on 'working best under pressure', European Journal of Personality, 15, 391-406.

Ferrari (2004): J. R. Ferrari, Trait procrastination in academic settings: An overview of students who engage in task delays, In: H. C. Schowuenburg, C. Lay, T. A. Pychyl, J. R. Ferrari (Eds.), Counseling the procrastinator in academic settings, Washington, DC: American Psychological Association, 19-28.

Ferrari, Tice (2000): J. R. Ferrari, D. M. Tice, Procrastination as a self-handicap for men and women: A task avoidance strategy in a laboratory setting, Journal of Research in Personality, 34, 73-83.

Finez, Sherman (2012): L. Finez, D. K. Sherman, Train in vain: The role of the self in claimed self-handicapping strategies, Journal of Sport and Exercise Psychology, 34(2), 600-620.

Gadbois, Sturgeon (2011): S. A. Gadbois, R. D. Sturgeon, Academic self-handicapping: Relationships with learning specific and general self-perceptions and academic performance over time, British Journal of Educational Psychology, 81(2), 207-222.

Harris, Snyder (1986): R. N. Harris, C. R. Snyder, The role of uncertain self-esteem in self-handicapping, Journal of Personality and Social Psychology, 51, 451-458.

Harris, Snyder, Higgins, Schrag (1986): R. N. Harris, C. R. Snyder, R. L. Higgins, J. L. Schrag, Enhancing the prediction of self-handicapping, Journal of Personality and Social Psychology, 51(6), 1191-1199.

Hirt, Deppe, Gordon (1991): E. R. Hirt, R. K. Deppe, L. J. Gordon, Self-reported versus behavioral self-handicapping: Empirical evidence for a theoretical distinction, Journal of Personality and Social Psychology, 61(6), 981-991.

Janis, Mann (1977): I. L. Janis, L. Mann, Decision making: a psychological analysis of conflict, choice, and commitment, New York: Free Press.

Jones, Rhodewalt (1982): E. E. Jones, F. Rhodewalt, The Self-handicapping Scale, available from F. Rhodewalt, Department of Psychology, University of Utah, Salt Lake City, UT.

Kolditz, Arkin (1982): T. A. Kolditz, R. M. Arkin, An impression management interpretation of the self-handicapping strategy, Journal of Personality and Social Psychology, 43(3), 492-502.

Lay (1986): C. H. Lay, At last, my research article on procrastination, Journal of Research in Personality, 20, 474-495. 
Leary, Shepperd (1986): M. R., Leary, J. A. Shepperd, Behavioral self-handicaps versus self-reported handicaps: A conceptual note, Journal of Personality and Social Psychology, 51(6), 1265-1268.

Leondari, Gonida (2007): A. Leondari, E. Gonida, Predicting academic self-handicapping in different age groups: The role of personal achievement goals and social goals, British Journal of Educational Psychology, 77(3), 595-611.

McCrea, Hirt, Hendrix, Milner, Steele (2008): S. McCrea, E. R. Hirt, K. L. Hendrix, B. J. Milner, N. L. Steele, The worker scale: Developing a measure to explain gender differences in behavioral self-handicapping, Journal of Research in Personality, 42(4), 949-970.

Milgram, Sroloff, Rosenbaum (1988): N. A. Milgram, B. Sroloff, M. Rosenbaum, The procrastination of everyday life, Journal of Research in Personality, 22, 197-212.

Milgram, Marshevskyb, Sadeh (1995): N. A. Milgram, S. Marshevskyb, C. Sadeh, Correlates of academic procrastination: Discomfort, task aversiveness, and task capability, The Journal of Psychology, 129(2), 145-155.

O'Connor (2000): B. P. O'Connor, SPSS and SAS programs for determining the number of components using parallel analysis and velicer's MAP test, Journal of the Psychonomic Society, Inc, 32(3), 396-402.

Rosenberg (1965): M. Rosenberg, Society and the adolescent self-image, Princeton, NJ: Princeton University Press.

Schraw, Wadkins, Olafson (2007): G. Schraw, T. Wadkins, L. Olafson, Doing the things we do: A grounded theory of academic procrastination, Journal of Educational Psychology, 99(1), 12-25.

Schwinger, Stiensmeier-Pelster (2011): M. Schwinger, J. Stiensmeier-Pelster, Prevention of self-handicapping: The protective function of mastery goals, Learning and Individual Differences, 21(6), 699-709.

Schlenker, Dlugolecki, Doherty (1994): B. R. Schlenker, D. W. Dlugolecki, K. Doherty, The impact of self-presentations on self-appraisals of behavior: The power of public commitment, Personality and Social Psychology Bulletin, 20, 20-33.

Smith, Hardy, Arkin (2009): J. L. Smith, T. Hardy, R. Arkin, When practice doesn't make perfect: Effort expenditure as an active behavioral self-handicapping strategy, Journal of Research in Personality, 43(1), 95-98.

Senecal, Koestner, Vallerand (1995): C. Senecal, R. Koestner, R. J. Vallerand, Selfregulation and academic procrastination, Journal of Social Psychology, 135, 607-619.

Solomon, Rothblum (1984): L. J. Solomon, E. Rothblum, Academic procrastination: Frequency and cognitive-behavioral correlates, Journal of Counseling Psychology, 31, 503-509.

Steel (2007): P. Steel, The nature of procrastination: A meta-analytic and theoretical review of quintessential self-regulatory failure, Psychological Bulletin, 133, 65-94.

Strube (1986): M. J. Strube, An analysis of the self-handicapping scale, Basic and Applied Social Psychology, 7, 211-224.

Tedeschi (1981): J. T. Tedeschi, Impression management theory and social psychological research, New York: Academic Press.

Tice, Baumeister (1997): D. M. Tice, R. F. Baumeister, Longitudinal study of procrastination, performance, stress, and health: The costs and benefits of dawdling, Psychological Science, 8(6), 454-458. 
Tuckman (1991): B. W. Tuckman, The development and concurrent validity of the procrastination scale, Educational and Psychological Measurement, 51, 473-480.

Urdan, Midgley (2001): T. Urdan, C. Midgley, Academic self-handicapping: What we know, what more there is to learn, Educational Psychology Review, 13(2), 115-138.

Van Eerde (2003): W. van Eerde, A meta-analytically derived nomological network of procrastination, Personality and Individual Differences, 35, 1401-1418.

Van Eerde (2004): W. van Eerde, Procrastination in academic settings and the Big Five model of personality: A meta-analysis, In: H. C. Schouwenburg, C. H. Lay, T. A. Pychyl, J. R. Ferrari (Eds.), Counseling the procrastinator in academic settings, Washington: American Psychological Association, 29-40.

Wagnild, Young (1993): G. Wagnild, H. Young, Development and Psychometric Evaluation of Resilience Scale, Journal of Nursing Measurement, 1, 165-178.

\section{Предраг Ж. Живковић}

Универзитет у Крагујевцу

Факултет педагошких наука у Јагодини

Катедра за друштвено-хуманистичке науке

\section{ОДЛАГАЮЕ АКАДЕМСКИХ ОБАВЕЗА И САМОХЕНДИКЕПИРАЮЕ СТУДЕНАТА: ПРОКРАСТИНАЦИЈА У АКАДЕМСКОМ КОНТЕКСТУ}

Резиме: Будући да не постоји јединствено прихваћена дефиниција, прокрастинација се обично дефинише као добровољно ирационално одлагање планираних активности, упркос знању да ће то имати негативне последице по појединца. Самохендикепирање, као стратегија за суочавање са потенцијалним неуспехом, јавља се када постоји претња самопоштовању, односно када се очекује неуспех у активности која је најчешће повезана са способношћу појединца. Тада особа активно тражи или ствара факторе који ометају обављање активности, што може послужити као оправдање за потенцијални неуспех. Циљ истраживања био је да се утврди веза између академске прокрастинације и самохендикепирања студената. Поред тога, на узорку од сто деведесет осам студената Факултета педагошких наука у Јагодини $(\mathrm{N}=198)$, испитана је факторска структура коришћених инструмената (Procrastination Scale (Tuckman 1991), Self-Handicapping Scale (Jones, Rhodewalt 1982)), интерна и дискриминативна валидност скала, као и предиктивна и класификациона вредност модела у стандардној и хијерархијској регресионој анализи (пол, ниво студија, прокрастинација, самохендикепирање, самопоштовање, резилијентност, импостеризам, изгарање, самоусмерено учење). Резултати показују да 54\% студената прокрастинише; да се прокрастинација објашњава једном димензијом, а самохендикепирање двема (показано и прокламовано самохендикепирање); да је корелација прокрастинације са показаним самохендикепирањем статистички значајна $(r=0.64)$, а да повезаност прокрастинације са прокламованим самохендикепирањем није статистички значајна $(\mathrm{r}=0.10)$; женски испитаници прокрастинишу више од мушких; слабији прокрасти- 
натори се другачије самохендикепирају, а јачи прокрастинатори се слично самохендикепирају; на основу стандардизованих ( $\beta$ ) бета коефицијената у регресионој анализи можемо закључити да су најјачи предиктори прокрастинације пол и прокламовано самохендикепирање. Ови подаци указују на релативно велик број оних који одлажу своје академске обавезе, па се може констатовати да је академска прокрастинација проблем епидемиолошких размера међу студентима.

Кључне речи: прокрастинација, самохендикепирање, академски контекст, корелациона анализа. 